\title{
Electrochemical Magnetic Immunosensors for the Determination of Ceruloplasmin
}

\author{
Irene Ojeda, María Moreno-Guzmán, Araceli González-Cortés, Paloma Yáñez-Sedeño,* José M. Pingarrón \\ Department of Analytical Chemistry, Faculty of Chemistry, University Complutense of Madrid, Ciudad Universitaria s/n, \\ 28040-Madrid, Spain \\ *e-mail: yseo@quim.ucm.es
}

Received: June 12, 2013

Accepted: July 8, 2013

Published online: $\mathbf{\square} \mathbf{\square}, 2013$

\begin{abstract}
Electrochemical immunosensors for ceruloplasmin $(\mathrm{Cp})$ are reported for the first time. Two configurations involving magnetic beads (MBs) functionalized with Protein A or Streptavidin for immobilization of Cp antibodies were compared, using competitive immunoassay with synthesized alkaline phosphatase-Cp conjugate. Upon capturing MBsimmunoconjugates onto screen-printed carbon electrodes, quantification of $\mathrm{Cp}$ was accomplished by DPV measurement of 1-naphtol generated after 1-naphtyl phosphate addition. Linear ranges of calibration curves and detection limits were $0.1-1000 \mu \mathrm{g} / \mathrm{mL}$ and $0.040 \mu \mathrm{g} / \mathrm{mL}$ (Protein A-MBs), and $0.025-20 \mu \mathrm{g} / \mathrm{mL}$ and $0.018 \mu \mathrm{g} / \mathrm{mL}$ (Strept-MBs). Good results were obtained in the determination of $\mathrm{Cp}$ in spiked human serum samples.
\end{abstract}

Keywords: Ceruloplasmin, Electrochemical magnetic immunosensor, Human serum

DOI: 10.1002/elan.201300269

Supporting Information for this article is available on the WWW under http://dx.doi.org/10.1002/elan.201300269.

\section{Introduction}

Ceruloplasmin $(\mathrm{Cp})$ is a copper-transporting $\alpha_{2}$-glyco-protein also known under the name of ferroxidase because of its oxidase activity towards ferrous ions [1]. Cp acts as a source of copper for peripheral organs where this element constitutes an essential cofactor for many enzymes [2]. The normal levels of $\mathrm{Cp}$ in serum are $250-470 \mu \mathrm{g} / \mathrm{mL}$ for women and $250-370 \mu \mathrm{g} / \mathrm{mL}$ for men [3]. The increased activity of $\mathrm{Cp}$ is an index of inflammation while the low levels $(<20 \mu \mathrm{g} / \mathrm{mL}$ in adults) are associated with Wilson's disease, an infrequent cause of chronic liver disease [4,5]. High concentration levels of $\mathrm{Cp}$ are particularly notable in diseases of the reticuloendothelial system such as Hodgkin's disease as well as during pregnancy or use of contraceptive pills [6]. Increased urinary excretion of $\mathrm{Cp}, \mathrm{IgG}$ and transferrin also predicts future development of microalbuminuria [7]. Several studies have also reported the positive correlations of body fat mass or weight gains with $\mathrm{Cp}$ and other inflammation sensitive plasma proteins (ISPs). It has been proposed that proinflammatory cytokines produced in the adipose tissue increase the hepatic synthesis of ISPs which are known as important cardiovascular diseases risk factors [8].

High serum levels of $\mathrm{Cp}$ have been found in patients with central obesity, these concentrations also being correlated with serum triglyceride and cholesterol levels and visceral fat accumulation [9]. Therefore, $\mathrm{Cp}$ among other ISPs can be used as a biomarker for obesity, particularly in relation with inflammation-associated proteins [8] Since Cp has been shown to increase in response to the atherosclerotic inflammatory process, the determination of this protein might also be a useful tool to identify patients with the highest risk for myocardial infarction [9].

Various colorimetric assays for $\mathrm{Cp}$ based on the oxidase activity of this protein with substrates such as $p$-phenylenediamine (PPD) $[10,11]$ or dianisidine (3,3'-dimethoxybenzidine) dihydrochloride [12] were reported in the earlier $70 \mathrm{~s}$. Later, kinetic methods using $N, N$-dimethyl- $p$ phenylenediamine monohydro-chloride (DPPD) [13] or $\mathrm{Fe}^{2+}[14,15]$ were also described. Turbidimetry $[5,16]$, inductively-coupled plasma mass spectrometry (ICPMS) [17] and stripping potentiometry [18] were also employed for the determination of Cp. Different immunoassays for this protein have been developed and commercial kits based on such immunoaffinity schemes are currently available. Some examples are summarized in Table 1, where the analytical performance of the kits, including information on the fundamentals of the methodologies, concentration ranges, limits of detection, precision, type of samples and assay time, have been collected.

Regarding immunosensors, only one example has been found in the literature consisting of a reusable piezo-immunosensor for $\mathrm{Cp}$ based on plasma-polymerized film (PPF) [19]. Anti-ceruloplasmin antibody (anti-Cp) was electrostatically adsorbed on the PPF-modified crystal through an oppositely charged polyelectrolyte layer of alginate. An optimized assay medium containing polyethy- 
Table 1. Comparison of the analytical performance of the developed magnetoimmunosensors with various immunoassay systems for ceruloplasmin (Cp). TMB: 3,3',5,5'-tetramethylbenzidine; PEG: poly(ethyleneglycol)

\begin{tabular}{|c|c|c|c|c|c|c|}
\hline Immunoassay system & Characteristics & $\begin{array}{l}\text { Range } \\
\text { (ng/mL) }\end{array}$ & $\begin{array}{l}L O D \\
(\mathrm{ng} / \mathrm{mL})\end{array}$ & $\begin{array}{l}\text { Precision, } \\
R S D \%\end{array}$ & Samples & $\begin{array}{l}\text { Assay } \\
\text { time }\end{array}$ \\
\hline $\begin{array}{l}\text { Electrochemical magneto- } \\
\text { immunosensor based on } \\
\text { SPCEs (this work) }\end{array}$ & $\begin{array}{l}\text { Competitive immunoassay with anti- } \\
\text { Cp-Protein A-MBs between Cp and } \\
\text { Cp-AP }\end{array}$ & $100-10^{6}$ & $40[\mathrm{a}]$ & $\begin{array}{l}5.3 \text { (intra- } \\
\text { assay) }\end{array}$ & Human serum & $50 \mathrm{~min}$ \\
\hline $\begin{array}{l}\text { Electrochemical magneto- } \\
\text { immunosensor based on } \\
\text { SPCEs (this work) }\end{array}$ & $\begin{array}{l}\text { Competitive immunoassay with anti- } \\
\text { Cp-Biotin-Strept-MBs between Cp and } \\
\text { Cp-AP }\end{array}$ & $\begin{array}{l}25- \\
2 \times 10^{4}\end{array}$ & $18[\mathrm{a}]$ & $\begin{array}{l}3.2 \text { (intra- } \\
\text { assay) }\end{array}$ & Human serum & $50 \mathrm{~min}$ \\
\hline $\begin{array}{l}\text { Assaypro Assay Max } \\
\text { Human Ceruloplasmin } \\
\text { ELISA Kit EC4001-1 }\end{array}$ & $\begin{array}{l}\text { Competitive immunoassay with pAb } \\
\text { between Cp and Biotin-Cp. Detect. } \\
\text { with Strept-HRP/TMB }\end{array}$ & $\begin{array}{l}630- \\
4 \times 10^{4}\end{array}$ & $\begin{array}{l}100[\mathrm{~b}] \\
\text { (buffer so- } \\
\text { lution) }\end{array}$ & $\begin{array}{l}4.0 \text { (intra- } \\
\text { assay); } 7.0 \\
\text { (inter-assay) }\end{array}$ & $\begin{array}{l}\text { Human plasma, } \\
\text { serum }\end{array}$ & $\begin{array}{l}2 \mathrm{~h} \\
47 \mathrm{~min}\end{array}$ \\
\hline $\begin{array}{l}\text { Uscn E90909Hu96 Tests } \\
\text { ELISA Kit (human) }\end{array}$ & $\begin{array}{l}\text { Sandwich immunoassay with mAb and } \\
\text { Biotin-pAb. Detection with Avidin- } \\
\text { HRP and TMB }\end{array}$ & $9.4-600$ & $<3.4[\mathrm{~b}]$ & $\begin{array}{l}<10 \text { (intra- } \\
\text { assay); }<12 \\
\text { (inter-assay }\end{array}$ & $\begin{array}{l}\text { Human serum, } \\
\text { plasma, tissue, } \\
\text { cell culture }\end{array}$ & $\begin{array}{l}3 \mathrm{~h} \\
45 \mathrm{~min}\end{array}$ \\
\hline $\begin{array}{l}\text { Uscn C90909Ra96 Tests } \\
\text { ELISA Kit (rat) }\end{array}$ & $\begin{array}{l}\text { Sandwich immunoassay with } \mathrm{Ab} \text { and } \\
\text { Biotin-Ab. Detection with Avidin-HRP } \\
\text { and TMB }\end{array}$ & $6.25-400$ & $2.01[\mathrm{~b}]$ & & $\begin{array}{l}\text { Rat serum, } \\
\text { plasma, other } \\
\text { biolog. fluids }\end{array}$ & $\begin{array}{l}3 \mathrm{~h} \\
45 \mathrm{~min}\end{array}$ \\
\hline Mybiosource MBS701656 & $\begin{array}{l}\text { Competitive immunoassay with } \mathrm{Ab} \text { and } \\
\text { HRP-Ab. Detect. with TMB }\end{array}$ & $\begin{array}{l}(1.5- \\
50) \times 10^{4}\end{array}$ & $\begin{array}{l}7500[\mathrm{~b}] \\
\text { (buffer so- } \\
\text { lution) }\end{array}$ & & $\begin{array}{l}\text { Human serum, } \\
\text { plasma }\end{array}$ & $\begin{array}{l}1 \mathrm{~h} \\
45 \mathrm{~min}\end{array}$ \\
\hline Abnova KA0469 & $\begin{array}{l}\text { Competitive immunoassay with pAb } \\
\text { between Cp and Biotin-Cp. Detect. } \\
\text { with Strept-HRP/TMB }\end{array}$ & $\begin{array}{l}630- \\
4 \times 10^{4}\end{array}$ & $\begin{array}{l}100[\mathrm{~b}] \\
\text { (buffer s } \\
\text { lution) }\end{array}$ & $\begin{array}{l}4.1 \text { (intra- } \\
\text { assay); } 7.2 \\
\text { (inter-assay) }\end{array}$ & $\begin{array}{l}\text { Human plasma, } \\
\text { serum }\end{array}$ & $\begin{array}{l}2 \mathrm{~h} \\
47 \mathrm{~min}\end{array}$ \\
\hline Abnova, KA0470 & $\begin{array}{l}\text { Sandwich immunoassay with } \mathrm{pAb} \text { and } \\
\text { Biotin-pAb. Detection with Strept- } \\
\text { HRP and TMB }\end{array}$ & $1.25-320$ & $\begin{array}{l}\sim 1[\mathrm{~b}] \\
\text { (buffer so- } \\
\text { lution) }\end{array}$ & $\begin{array}{l}4.1 \text { (intra- } \\
\text { assay); } 7.1 \\
\text { (inter-assay) }\end{array}$ & $\begin{array}{l}\text { Human urine, } \\
\text { saliva, milk, cell } \\
\text { culture }\end{array}$ & $\begin{array}{l}3 \mathrm{~h} \\
40 \mathrm{~min}\end{array}$ \\
\hline $\begin{array}{l}\text { Pro Alt Human Ceruloplas- } \\
\text { min ELISA Quantitation Kit } \\
\text { PRO-20074F }\end{array}$ & $\begin{array}{l}\text { Sandwich immunoassay with } \mathrm{Ab} \text { and } \\
\text { HRP-Ab. Detection with Avidin-HRP } \\
\text { and TMB }\end{array}$ & $3.9-250$ & No data & No data & $\begin{array}{l}\text { Human serum, } \\
\text { other biolog. } \\
\text { samples }\end{array}$ & $4 \mathrm{~h}$ \\
\hline $\begin{array}{l}\text { MDbioproducts Human cer- } \\
\text { uloplasmin MO46029 }\end{array}$ & $\begin{array}{l}\text { Competitive immunoassay with pAb } \\
\text { between Cp and Biotin-Cp. Detect. } \\
\text { with Strept-HRP/TMB }\end{array}$ & $\begin{array}{l}630- \\
2 \times 10^{4}\end{array}$ & $\begin{array}{l}<60[\mathrm{~b}] \\
\text { (buffer so- } \\
\text { lution) }\end{array}$ & $\begin{array}{l}4.2 \text { (intra- } \\
\text { assay); } 7.3 \\
\text { (inter-assay) }\end{array}$ & $\begin{array}{l}\text { Human serum, } \\
\text { plasma }\end{array}$ & $\begin{array}{l}2 \mathrm{~h} \\
40 \mathrm{~min}\end{array}$ \\
\hline $\begin{array}{l}\text { Piezoimmunosensor based } \\
\text { on PPF-modified crystal [19] }\end{array}$ & $\begin{array}{l}\text { Immobilization of Ab onto alginate } \\
\text {-PPF QCM. Immuno-assay in the pres- } \\
\text { ence of PEG }\end{array}$ & $\begin{array}{l}310- \\
2.7 \times 10^{4}\end{array}$ & $150(3 \sigma)$ & $\begin{array}{l}6.2 \text { (intra- } \\
\text { assay) }\end{array}$ & Human serum & $\begin{array}{l}2 \mathrm{~h} \\
15 \min \end{array}$ \\
\hline
\end{tabular}

[a] see used equation in the text; [b] minimum detectable concentration.

lene glycol (PEG) was used to enhance immunosensing response and a linear concentration range between 0.31 and $27.0 \mu \mathrm{g} / \mathrm{mL}$ with a detection limit of $0.15 \mu \mathrm{g} / \mathrm{mL} \mathrm{Cp}$ were reported (see Table 1 ).

On the other hand, electrochemical magnetoimmunosensors have demonstrated to be useful bioanalytical tools combining the excellent capabilities of electrochemical transduction in terms of sensitivity, low cost, rapidity of the measurements and ability for portable screening with the special characteristics of functionalized magnetic beads (MBs) [20-23]. The large active surface area of MBs enables the immobilization of high antibody loadings, and the magnetic properties facilitate the optimization of the experimental conditions providing a high sensitivity together with a decrease of matrix effect and minimizing unspecific bindings on the electrode [24].

This paper reports, for the first time, the preparation of electrochemical immunosensors for $\mathrm{Cp}$. These immunosensors involved the use of functionalized magnetic microparticles and two different configurations implying MBs functionalized with protein $\mathrm{A}$ or strept-avidin for the immobilization of anti-Cp or biotinylated-Cp antibodies, respectively were tested and compared. Oriented immobilization onto an electrode surface through protein A due to its binding capacity with the Fc region of antibodies [25] has demonstrated to lead to highly efficient immunoreactions with enhanced performance of the detection system [26]. Moreover, it is well known that the attachment of proteins through the specific streptavidinbiotin interaction, characterized by a high affinity constant, constitutes also an effective and reliable approach for the stable immobilization of antibodies [27,28]. The immunosensor configurations described in this work are based on competitive type immunoassays involving $\mathrm{Cp}$ and the alkaline phosphatase (AP)-labeled Cp conjugate which was synthesized in the laboratory. Once the immunoaffinity reaction occurred on the modified MBs, AP$\mathrm{Cp} / \mathrm{Cp}$-anti-Cp-Protein A-MBs or AP-Cp/Cp-anti-CpBiotin-Strept-MBs conjugates were captured on the surface of a screen-printed carbon electrode (SPCE) with a small magnet, and the quantification of $\mathrm{Cp}$ was accomplished by measuring the differential pulse voltammetric

\footnotetext{
21 www.electroanalysis.wiley-vch.de 
(DPV) responses for the enzymatically generated 1-naphtol formed upon 1-naphtyl phosphate additions.

\section{Experimental}

\subsection{Reagents and Solutions}

A $1.1 \mathrm{mg} / \mathrm{mL}$ stock solution of biotinylated anti-ceruloplasmin rabbit polyclonal antibody (anti-Cp-Biotin, randomly, non oriented, biotinylated, Abcam) was prepared by suitable dilution with a PBST buffer solution composed of $10 \mathrm{mM} \mathrm{K} \mathrm{K}_{2} \mathrm{HPO}_{4} / \mathrm{KH}_{2} \mathrm{PO}_{4}$ buffer of $\mathrm{pH} 7.4$, $2.7 \mathrm{mM} \mathrm{KCl}$ and $0.05 \%$ Tween 20 . A $1.0 \mathrm{mg} / \mathrm{mL}$ anti-ceruloplasmin (anti-Cp, Abcam) stock solution was also prepared in PBST of $\mathrm{pH} 8.2$. A $7.14 \mathrm{mg} / \mathrm{mL}$ stock solution of human $\mathrm{Cp}$ was prepared from the commercial product (Abcam) with $0.1 \mathrm{M}$ Tris- $\mathrm{HCl}$ and $1 \mathrm{mM} \mathrm{MgCl}_{2}, \mathrm{pH} 7.2$, solution. Alkaline phosphatase-labeled ceruloplasmin (AP-Cp) was prepared as described below. $2 \%(\mathrm{w} / \mathrm{v})$ bovine serum albumin (BSA, Type H2) and D-biotin solutions were prepared from the commercial products (Gerbu) dissolved in a $0.1 \mathrm{M}$ Tris- $\mathrm{HCl}$ and $1 \mathrm{mM} \mathrm{MgCl}$ pH 7.2 solution. A Trizma base (Sigma, 99\%) and $1 \mathrm{mM}$ $\mathrm{MgCl}_{2}$ (Panreac, $99 \%$ ) buffer solution of $\mathrm{pH} 9.0$ (Trizma buffer) was also employed. $0.05 \mathrm{M}$ 1-naphtylphosphate (1-NPP, Fluka) solutions were prepared by dilution with Trizma buffer. Magnetic beads activated with protein A (Protein A-MBs) or streptavidin (Strept-MBs) (Dynabeads) were from Invitrogen. For the cross-reactivity assays, bilirubin, cholesterol, hemoglobin and human immunoglobulin, all from Sigma, were tested.

\subsubsection{Sample}

The analyzed sample was lyophilized human serum S7394 from Sigma spiked with $\mathrm{Cp}$ at 1000, 500, 250, 100 and $50 \mathrm{mg} / \mathrm{L}$ concentration levels. The solid serum was reconstituted in $1 \mathrm{~mL}$ of Tris- $\mathrm{HCl}$ solution of $\mathrm{pH} 7.2$ by mixing up to total dissolution.

\subsection{Apparatus and Electrodes}

All electrochemical measurements were carried out using a PGSTAT 12 potentiostat from Autolab. The electrochemical software was the general-purpose electrochemical system (GPES) (EcoChemie B.V.). Screen-printed carbon electrodes ( $4 \mathrm{~mm}$ diameter) were purchased from DropSens (Oviedo, Spain) and used as the working electrodes. These electrodes include a silver pseudo-reference electrode and a carbon counter electrode. All experiments were performed in an incubator at $T=25^{\circ} \mathrm{C}$. A PSelecta ultrasonic bath, an Optic Ivymen System constant temperature incubator shaker (Comecta S.A.) and a P-Selecta Agimatic magnetic stirrer, all distributed by Scharlab, were also used. $\mathrm{pH}$ measurements were made with a precision Metrohm Herisau E-510 pH-meter. A Vortex (Heidolph) stirrer, a neodymium magnet (AIMAN GZ) and a DynaMag-2 magnetic separator (Invitrogen, Dynal AS) were also used.

\subsection{Procedures}

\subsubsection{Preparation of Alkaline Phosphatase-Labeled Ceruloplasmin ( $A P-C P)$}

The Easy Link Alkaline Phosphatase Conjugation kit $(3 \times$ $100 \mathrm{mg} / \mathrm{L}$, Abcam) was used to prepare AP-Cp following the instructions from the supplier. Briefly, $50 \mu \mathrm{L}$ of $2 \mathrm{mg} /$ $\mathrm{mL} \mathrm{Cp}$ solution were treated with $5 \mu \mathrm{L}$ of the modifier in an Eppendorf tube. Then, the resulting solution was added to the AP mix vial and allowed reacting for three hours at $25^{\circ} \mathrm{C}$. Thereafter, $5 \mu \mathrm{L}$ of quencher solution were added and left to stand for $30 \mathrm{~min}$. Finally, $50 \mu \mathrm{L}$ of glycerol preservative were added. The resulting solution contained $1 \mathrm{mg} / \mathrm{mL}$ AP-Cp in $50 \%(\mathrm{v} / \mathrm{v})$ glycerol.

\subsubsection{Preparation of the Anti-Cp-Protein A-MBs and Anti-Cp-Biotin-Strept-MBs Immunosensors}

$1 \mu \mathrm{L}(30 \mu \mathrm{g})$ of the Protein A-MBs suspension or $3 \mu \mathrm{L}$ $(30 \mu \mathrm{g})$ of the Strept-MBs suspension were added to a 1.5-mL Eppendorf tube, washed twice with PBST buffer solution of $\mathrm{pH} 8.2$ or 7.4, respectively, and re-suspended in $25 \mu \mathrm{L}$ of a $2.5 \mu \mathrm{g} / \mathrm{mL}$ anti-Cp solution in PBST buffer of $\mathrm{pH} 8.2$ (Protein A-MBs), or in $25 \mu \mathrm{L}$ of a $10 \mu \mathrm{g} /$ $\mathrm{mL}$ anti-Cp-Biotin solution in PBST buffer of $\mathrm{pH} 7.4$ (Strept-MBs). Each washing step consisted of a resuspension of the beads in the washing solution and gentle stirring for $1 \mathrm{~min}$ followed by separation with the magnet for $2 \mathrm{~min}$ and removal of the solution. After incubation at $25^{\circ} \mathrm{C}$ under stirring at $950 \mathrm{rpm}$ for 15 minutes, anti-CpProtein A-MBs or anti-Cp-Biotin-Strept-MBs conjugates were sequentially washed with $\mathrm{B} \& \mathrm{~W}$ buffer solution of $\mathrm{pH} 8.2$ or $\mathrm{pH} 7.4$, respectively, and with Tris- $\mathrm{HCl}$ buffer solution. Then, $25 \mu \mathrm{L}$ of a mixture of $5 \mu \mathrm{g} / \mathrm{mL}$ AP-Cp and $\mathrm{Cp}$ of variable concentration in Tris- $\mathrm{HCl}$ (Protein A$\mathrm{MBs}$ ), or $1 \mu \mathrm{g} / \mathrm{mL} \mathrm{AP-Cp}$ and Cp of variable concentration in Tris- $\mathrm{HCl}$ and $2 \%$ BSA (Strept-MBs), were added and incubation was performed for 30 minutes at $25^{\circ} \mathrm{C}$ under continuous stirring. Thereafter, AP-Cp/Cp-anti-CpProtein A-MBs or AP-Cp/Cp-anti-Cp-biotin-Strept-MBs conjugates were washed three times with Tris- $\mathrm{HCl}$ buffer and re-suspended in Trizma buffer of $\mathrm{pH}$ 9. Then, $45 \mu \mathrm{L}$ of the corresponding suspension were transferred onto the surface of a SPCE, where MBs bearing the immunoconjugates were captured by placing a small neodymium magnet on the bottom part of the electrode. Finally, $5 \mu \mathrm{L}$ of the $50 \mathrm{mM}$ 1-naphthyl-phosphate solution were added to the electrode surface and, after reaction for 5 minutes, a differential pulse voltammogram (step potential $=$ $0.005 \mathrm{~V}$, amplitude $=0.07 \mathrm{~V}$ ) was recorded between -0.15 and $+0.60 \mathrm{~V}$ vs. Ag. Unless otherwise mentioned, all measurements were carried out in triplicate. 


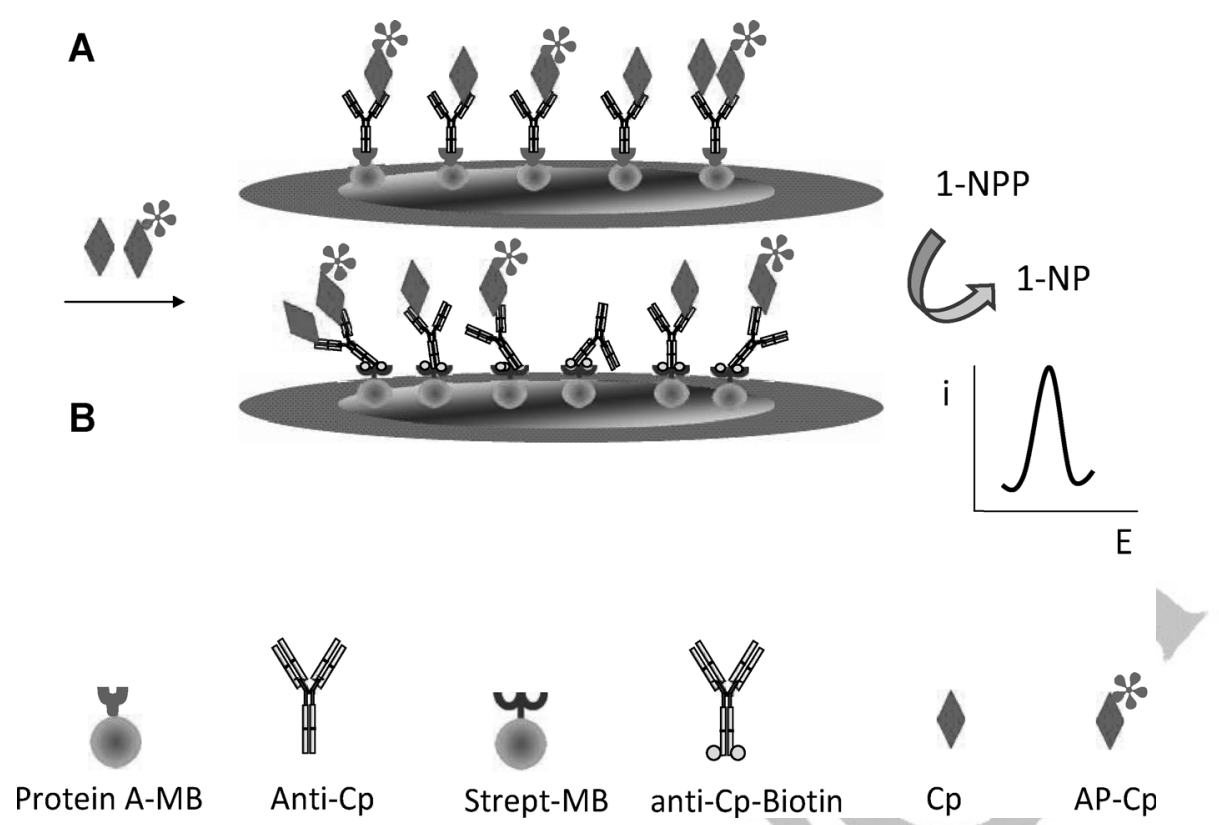

Fig. 1. Schematic display of the electrochemical immunosensors for $\mathrm{Cp}$ using (A) AP-Cp/Cp-anti-Cp-Protein A-MBs or (B) AP-Cp/ Cp-anti-Cp-Biotin-Strept-MBs conjugates.

\section{Results and Discussion}

A scheme of the immobilized immunoconjugates on the electrode surface and the electrochemical transduction step is illustrated in Figure 1. The experimental procedures described in Section 2.3.2 involved anti-Cp immobilization on Protein A-MBs and biotinylated anti-Cp antibody immobilization on Strept-MBs. Thereafter, in both cases, competitive-type immunoassays were employed involving $\mathrm{Cp}$ and AP-Cp. The immuno-conjugates composed of $\mathrm{AP}-\mathrm{Cp} / \mathrm{Cp}$-anti-Cp-Protein $\mathrm{A}-\mathrm{MBs}$ or $\mathrm{AP}-\mathrm{Cp} /$ $\mathrm{Cp}$-anti-Cp-Biotin-Strept-MBs were then retained onto a SPCE surface by means of a small neodymium magnet located at the bottom part of the electrode. The affinity reaction was monitored by adding 1-naphtylphosphate as the AP substrate and measuring at the SPCE the differential pulse voltammetric (DPV) oxidation peak of 1naphtol generated in the AP enzyme reaction.

\subsection{Optimization of the Performance Conditions of the anti-Cp-Protein A-MBs and Anti-Cp-Biotin-Strept- MBs Immunosensors}

The experimental variables affecting the analytical performance of both magnetoimmunosensor designs for $\mathrm{Cp}$ were optimized. The amount of functionalized MBs was fixed to $30 \mu \mathrm{g}$ taking into account previous results [29]. In the case of the anti-Cp-Protein A-MBs configuration, the optimization studies included the influence of: a) the antibody loading onto the functionalized MBs for various AP-Cp concentrations ranging between 1 and $50 \mu \mathrm{g} / \mathrm{mL}$, in the absence of $\mathrm{Cp}$; b) the anti-Cp loading for different $\mathrm{Cp}$ concentrations at the AP-Cp concentration corresponding to the saturation level; c) the incubation time of
anti-Cp onto Protein A-MBs; d) the time needed for competition between $\mathrm{Cp}$ and $\mathrm{AP}-\mathrm{Cp}$; e) the 1-naphthylphosphate concentration; f) the time required for the AP enzyme reaction to proceed. Details on these optimization studies can be found in the text and Figures S1 and S2 of Supporting Information. The variables ranges checked and the selected values for all of them are summarized in Table 2. Similarly, the following experimental variables affecting the voltammetric response of the antiCp-Biotin-Strept-MBs immunosensors were optimized: a) the loading of biotinylated antibody onto the Strept-MBs using $1 \mu \mathrm{g} / \mathrm{mLL}$ this sentence doesn't finish here,

$\mathrm{AP}-\mathrm{Cp}$; b) the concentration of AP-Cp; c) the incubation time of anti-Cp-Biotin onto Strept-MBs; d) the 1naph-thyl-phosphate concentration; e) the time required for the AP enzyme reaction to proceed. Figures S3 and S4 in Supplementary material show the experimental graphs obtained with these studies. Table 2 also summarizes the tested ranges and the selected values.

Looking at Table 2, it is interesting to notice that the optimum concentrations of antibody and AP-Cp are different in both configurations (larger and smaller, respectively, for the anti-Cp-Biotin-Strept-MBs immunosensors). This is most likely due to the differences in the ability for the antibody orientation with both functionalized MBs. So, when Protein A-MBs are used, an oriented antibody immobilization is produced and a lower loading is required to cover the $\mathrm{MBs}$ binding sites.

Moreover, a higher AP-Cp concentration will be needed to saturate the binding positions of the antibodies. On the contrary, when anti-Cp-Biotin-Strept-MBs are constructed, the antibody immobilization is not oriented and, consequently, it is less efficient and a higher concentration to obtain the largest response is required. At this 
Table 2. Optimization of the performance conditions of the anti-Cp-Protein A-MBs (a) and anti-Cp-Biotin-Strept-MBs (b)

\begin{tabular}{lll}
\hline & Range evaluated & Selected value \\
\hline (a) Tested variable & & 2.5 \\
Anti-Cp $(\mu \mathrm{g} / \mathrm{mL})$ & $0-10$ & 5 \\
AP-Cp $(\mu \mathrm{g} / \mathrm{mL})$ & $1-50$ & 15 \\
Incubation time of anti-Cp onto Protein A-MBs (min) & $15-60$ & 30 \\
Time needed for competition between Cp and AP-Cp (min) & $15-60$ & 5 \\
1-Naphthylphosphate concentration (mM) & $0.5-100$ & $5-12$ \\
Time required for the AP enzyme reaction to proceed (min) & & 5 \\
(b) Tested variable & $1-20$ & 10 \\
Anti-Cp-Biotin $(\mu \mathrm{g} / \mathrm{mL})$ & $0.5-5$ & 1 \\
AP-Cp $(\mu \mathrm{g} / \mathrm{mL})$ & $15-60$ & 15 \\
Incubation time of anti-Cp-Biotin onto Strept-MBs (min) & $15-60$ & 30 \\
Time needed for competition between Cp and AP-Cp (min) & $0.5-100$ & 5 \\
1-Naphthylphosphate concentration (mM) & $0-12$ & 5 \\
Time required for the AP enzyme reaction to proceed (min) & \\
\hline
\end{tabular}

situation, a lower concentration of AP-Cp is needed. In the case of anti-Cp-Biotin-Strept-MBs immunosensors, we observed experimentally that a blocking step with $2 \%$ BSA was necessary in order to minimize nonspecific binding of immunoreagents. This was in agreement with the findings obtained by other authors [30].

\subsection{Analytical Characteristics of the Magnetoimmunosensors}

Figure 2 compares the calibration plots constructed for $\mathrm{Cp}$ using both AP-Cp/Cp-anti-Cp-Protein A-MBs/SPCE (a) or $\mathrm{AP}-\mathrm{Cp} / \mathrm{Cp}$-anti-Cp-Biotin-Strept-MBs/SPCE (b) immunosensor configurations under the optimized working conditions stated above. The displayed error bars were calculated from measurements carried out with three different immunosensors in each case. The $i_{\mathrm{p}}$ vs. Cp immunosensors-concentration curve was fitted by nonlinear regression using the Sigma Plot data analysis software. The adjusted equation ( $r=0.997$ in both cases) was:

$y=i_{\min }+i_{\text {max }}-i_{\min }\left[1+\left(E C_{50} / x\right)\right]^{-k} \nwarrow \underset{\text { Change the letter }}{\text { "k" by an "h" }}$

where $i_{\max }$ and $i_{\min }$ are the maximum and minimum peak current values in the calibration graph (see Table 3 ). The $E C_{50}$ values, which correspond to the $\mathrm{Cp}$ concentration producing a fifty per cent competition, were $4.7 \pm 1.8$ and $0.9 \pm 0.1 \mu \mathrm{g} / \mathrm{mL}$ for the Protein A-MBs and the StreptMBs immunosensor configurations, respectively, with Hill slope values, $h$, of $-0.40 \pm 0.06$ and $-0.51 \pm 0.06$, respectively. The ranges of linearity were between 0.1 and $1000 \mu \mathrm{g} / \mathrm{mL}(r=0.995)$ with the immunosensor using Protein A-MBs, and between 0.025 and $20 \mu \mathrm{g} / \mathrm{mL}(r=0.993)$ for the anti-Cp-Biotin-Strept-MBs immunosensor. The

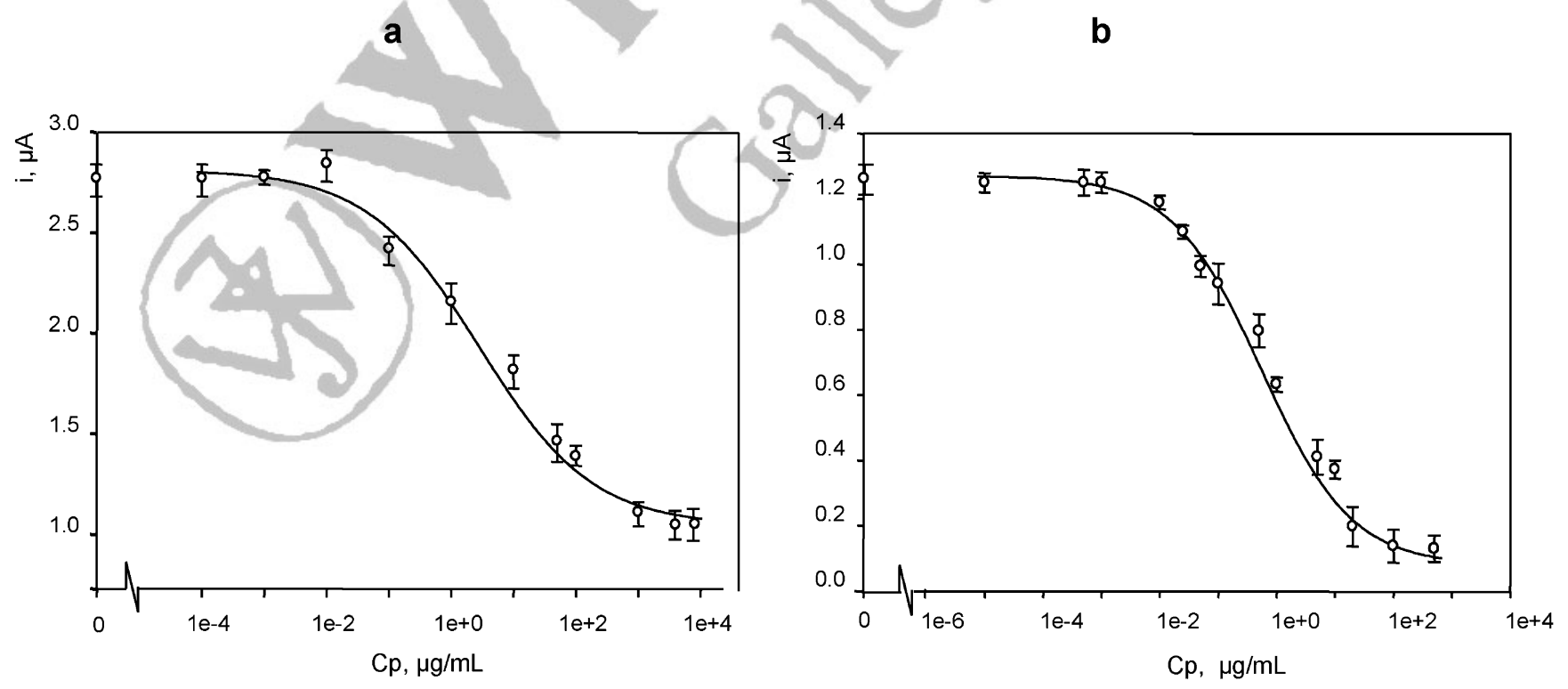

Fig. 2. Calibration plots constructed for Cp using AP-Cp/Cp-anti-Cp-Protein A-MBs/SPCE (a) and AP-Cp/Cp-anti-Cp-Biotin-StrepMBs/SPCE (b). 
Table 3. Analytical characteristics of the magnetoimmunosensors constructed for Cp using anti-Cp-Protein A-MBs or anti-Cp-BiotinStrept-MBs conjugates.

\begin{tabular}{lcc}
\hline Conjugate & anti-Cp-Protein A-MBs & anti-Cp-Biotin-Strept-MBs \\
\hline Linear range $(\mu \mathrm{g} / \mathrm{mL})$ & $0.1-1000$ & $0.025-20$ \\
& $r=0.995$ & $r=0.993$ \\
$E C_{50}(\mu \mathrm{g} / \mathrm{mL})$ & $4.7 \pm 1.8$ & $0.9 \pm 0.1$ \\
Hill slope & $-0.40 \pm 0.06$ & $-0.51 \pm 0.06$ \\
$i_{\min }(\mu \mathrm{A})$ & $0.94 \pm 0.09$ & $0.054 \pm 0.05$ \\
$i_{\max }(\mu \mathrm{A})$ & $2.84 \pm 0.07$ & $1.28 \pm 0.03$ \\
$L O D(\mu \mathrm{g} / \mathrm{mL})$ & 0.04 & 0.018 \\
$r$ & 0.996 & 0.997 \\
\hline
\end{tabular}

achieved limits of detection, 0.04 and $0.018 \mu \mathrm{g} / \mathrm{mL}$, respectively, were calculated from the equation:

$L O D=E C_{50}\left\{i_{\max }-i_{\min }\left(i_{\max }-i_{\min }-3 s\right)^{-1}-1\right\}^{-1 / h}$

where $s$ is the standard deviation $(n=10)$ of the zero value (the $i_{\mathrm{p}}$ value measured in the absence of $\mathrm{Cp}$, $\pm 0.08 \mu \mathrm{A}$ or $\pm 0.05 \mu \mathrm{A}$, respectively). Furthermore, quantification limits can be estimated as the lowest analyte concentration that can be measured in the linear portion of the corresponding calibration plots $(0.1$ and $0.025 \mu \mathrm{g} /$ $\mathrm{mL}$ for AP-Cp/Cp-anti-Cp-Protein A-MBs/SPCE and AP-Cp/Cp-anti-Cp-Biotin-Strept-MBs/SPCE immunosensors, respectively). The differences found in the analytical characteristics obtained with both magnetoimmunosensor designs arise probably from the above mentioned oriented or not oriented antibody immobilization. As mentioned already, the immunosensor using Protein A-MBs required a larger AP-Cp loading to saturate the oriented anti-Cp antibody.

Therefore, the competition of the analyte with AP-Cp was less favorable thus giving rise to a higher upper $\mathrm{Cp}$ concentration in the calibration graph as well as to higher limit of detection. On the contrary, a smaller AP-Cp loading was needed to saturate the not oriented anti-CpBiotin immobilized on Strept-MBs with the consequent easier competition between AP-Cp and $\mathrm{Cp}$ and the lower upper concentration in the calibration plot and the calculated limit of detection.

The reproducibility of the DP voltammetric measurements was evaluated with different immunosensors fabricated in the same day for solutions containing no $\mathrm{Cp}$. Relative standard deviation ( $R S D)$ values of 5.2 and $3.2 \%(n=8)$ were obtained for the anti-Cp-Protein AMBs and anti-Cp-Biotin-Strept-MBs immunosensors, respectively. These values demonstrated the reliability of the immunosensor preparation procedures for both configurations.

These analytical characteristics were compared with those reported for the different immunoassay systems collected in Table 1. As it can be seen, the developed electrochemical magnetoimmunosensors provided the widest analytical linear ranges as well as limits of detection ranking among the lowest despite the difficulty of this comparison due to the different criteria used for $L O D$ calcu- lation. In addition, the immunosensors provided precise results with low $R S D$ values. In particular, the anti-CpBiotin-Strept-MBs immunosensor provided the lowest $R S D$ value among the reported data.

Moreover, a relevant advantageous difference relied on the short assay time requiring only $50 \mathrm{~min}$ for the immunoconjugate preparation and the competitive immunoassay including the coupled enzyme reaction. Therefore, the whole assay, including the voltammetric detection, can be performed in approximately one hour which is much shorter than the time required for the immunoassays listed in Table 1 . The storage stability of the anti-Cp-Protein A-MBs and anti-Cp-Biotin-Strept-MBs immunoconjugates in $0.1 \mathrm{M}$ Tris- $\mathrm{HCl}$ or PBST solution at $8^{\circ} \mathrm{C}$ was investigated. Various immunoconjugates were prepared on the same day, stored and used to construct the corresponding immunosensors in different days. As an example, Figure 3 shows the control chart for the currents measured with the anti-Cp-Biotin-Strept-MBs magnetoimmunosensors for solutions containing no $\mathrm{Cp}$ upon storage in both buffer solutions. As it can be seen, the current was below the lower limit of control after seven days of storage (Figure 3a), and then decreased when the immunosensors were stored in $0.1 \mathrm{M}$ Tris- $\mathrm{HCl}$, which was attributed to the observed magnetoimmunoconjugate agglutination. On the contrary, magnetoimmunosensors prepared with immunoconjugates stored in PBST (Figure 3b) provided measurements inside the control limits for at least 42 days. This largely improved stability was probably due to the effect of the Tween 20 surfactant present in PBST which enhanced the microparticles dispersion avoiding their agglutination. It is important to remark that this stability permits the preparation of one batch of immunoconjugates, their storage under the described conditions, and the fabrication of the immunosensor just before the analysis is performed. For example, this protocol allows a single determination to be made in approximately 35 min when using anti-Cp-Biotin-Strept-MBs. Similar results were obtained for studies on the storage stability with anti-Cp-Protein A-MBs immunosensors.

\subsection{Selectivity Studies}

Figure 4 shows the responses obtained with both magnetoimmunosensor designs in serum containing no $\mathrm{Cp}$ and 

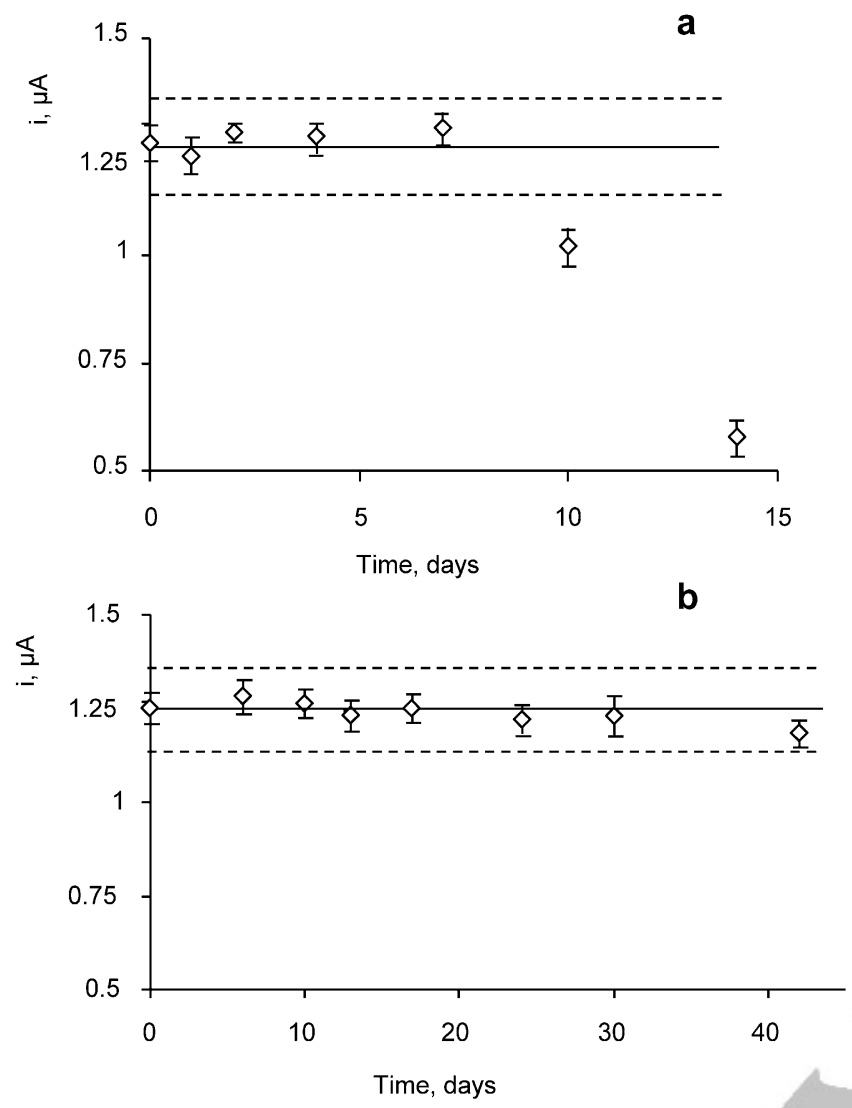

Fig. 3. Control charts constructed to check the stability of anti$\mathrm{Cp}$-Biotin-Strept-MBs conjugates upon storage in (a) Tris- $\mathrm{HCl}$ and (b) PBST buffer solutions. The central value was set as the average response obtained for eight measurements of different solutions containing no $\mathrm{Cp}$; upper and lower limits of control were set as $\pm 3 \times$ the standard deviation of these measurements.

diluted with Tris-HCl buffer to different dilution ratios. As it can be observed, a strong matrix effect occurred in both cases. However, while this effect could be completely removed upon a 1:1000 dilution for the immunosensors prepared with anti-Cp-Biotin-Strept-MBs, any dilution was sufficient to avoid the matrix effect in the case of anti-Cp-Protein A-MBs. These results were attributed to the high selectivity of the Biotin-Streptavidin bond preventing the interaction with other serum proteins. Taking into account this behavior, $\longleftarrow$ this sentence doesn't finish here,

only the immunosensor using the anti-Cp-BiotinStrept-MBs conjugate was employed for the analysis of the serum sample.

In order to go more deeply into the observed decrease in the immunosensor response at low serum dilutions, the effect of various species: bilirubin, hemoglobin, cholesterol, albumin and human serum immunoglobulin, which may be present in biological fluids together with $\mathrm{Cp}$, was tested. The obtained results for solutions containing no $\mathrm{Cp}$ and different concentration levels of the checked compounds, corresponding to those expected in serum at $1: 1000$ or $1: 100$ dilutions $(1: 10$ in the case of albumin $)$ are summarized in Figure 5.
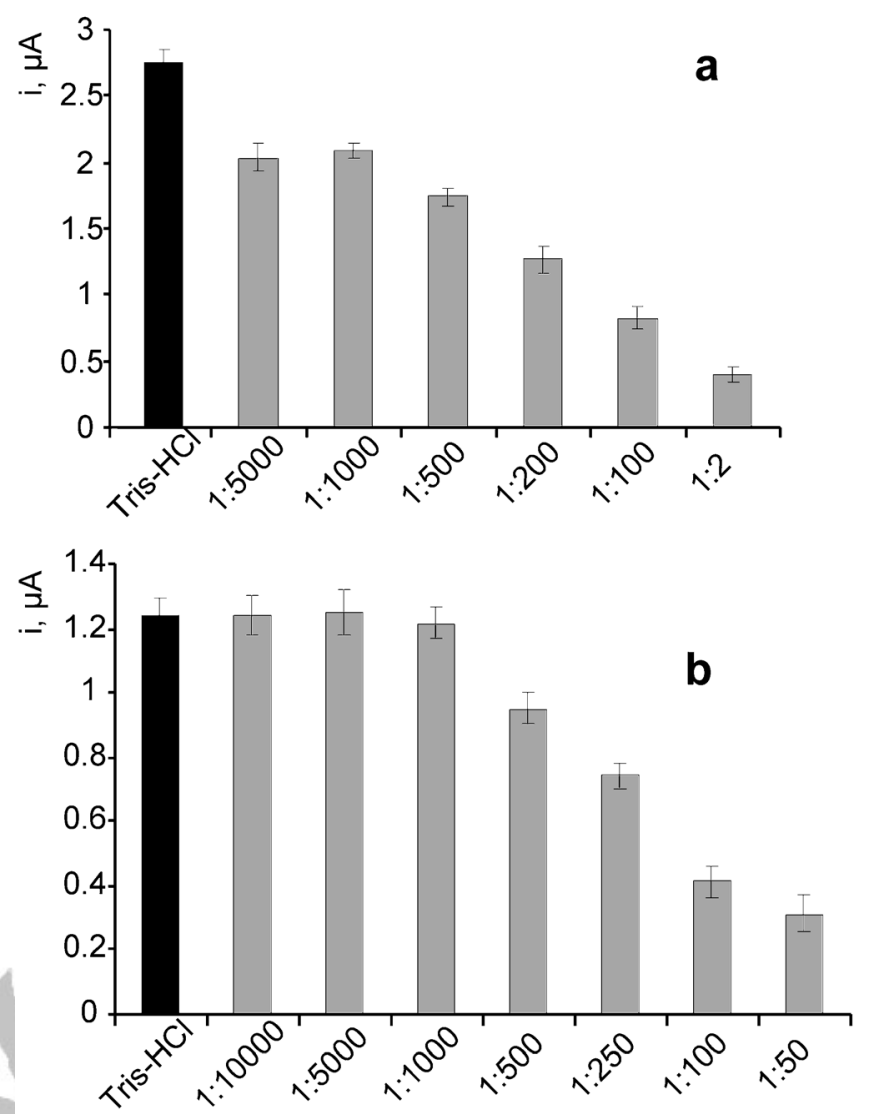

Serum dilution: Human Serum: Tris- $\mathrm{HCl}$

Fig. 4. Effect of human serum dilution with Tris-HCl buffer on the DPV response in the absence of $\mathrm{Cp}$ measured with $\mathrm{AP}-\mathrm{Cp} /$ Cp-anti-Cp-Protein A-MBs/SPCE (a) and AP-Cp/Cp-anti-CpBiotin-Strept-MBs/SPCE immunosensors.

Moreover, according to the specifications of the supplier, the effect of the presence of sodium ion was also evaluated. As it can be observed, the immunosensor responses were similar in all cases to that measured in the absence of the other proteins or cholesterol, thus demonstrating the excellent selectivity for the determination of $\mathrm{Cp}$ in biological fluids. Particularly interesting is the effect of sodium ion. Although the presence of this ion at 1.5 and $15 \mathrm{mM}$, which corresponded to the expected levels in serum diluted at 1:100 and 1:10 ratios, respectively, produced a slight decrease in the immunosensor response, no noticeable effect was observed at the ion concentration level for the selected 1:1000 dilution factor. Therefore, it can be concluded that the immunosensor selectivity was very good under the conditions employed for the determination of $\mathrm{Cp}$ in human serum.

\subsection{Determination of $\mathbf{C p}$ in Human Serum}

As commented above, the anti-Cp-Biotin-Strept-MBs/ SPCE magnetoimmunosensor was used for the determination of $\mathrm{Cp}$ in spiked human serum samples. Firstly, a calibration plot was constructed from the reconstituted sample, 1:1000 diluted, and containing $\mathrm{Cp}$ in the 0.05 to 


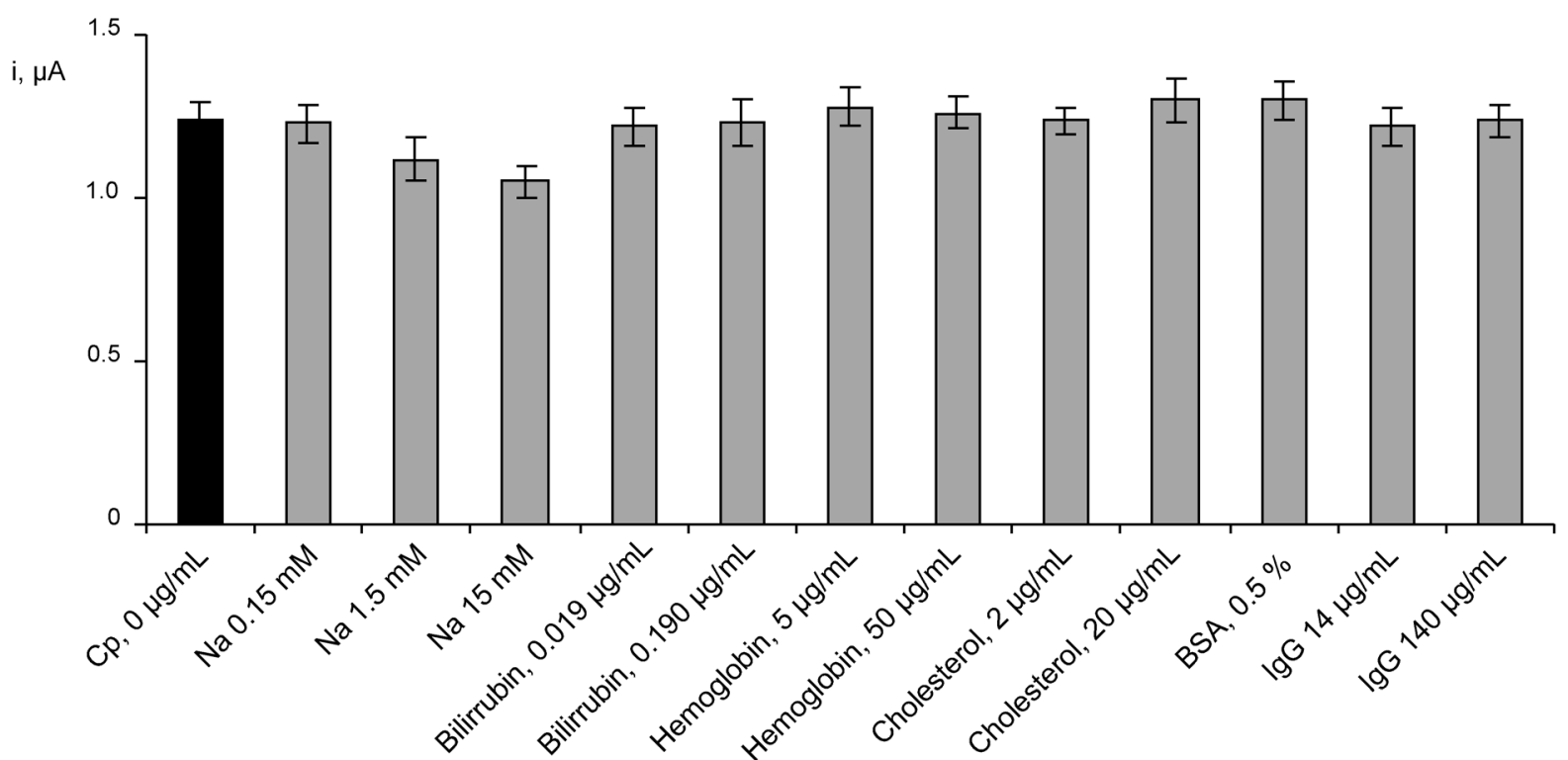

Fig. 5. Selectivity studies for AP-Cp/Cp-anti-Cp-Biotin-Strept-MBs/SPCE immunosensors. DPV responses obtained in the absence of Cp. See text for details.

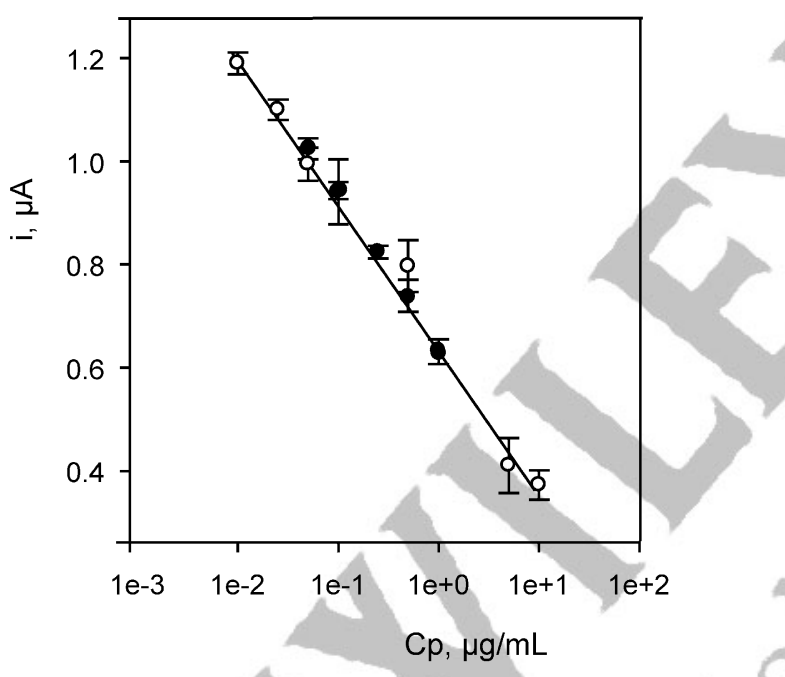

Fig. 6. A comparison of the linear portions of the calibration plots constructed for $\mathrm{Cp}$ in reconstituted 1: 1000 diluted human serum (black dots), and standard Cp solutions (white dots).

$1.00 \mu \mathrm{g} / \mathrm{mL}$ concentration range. As it is displayed in Figure 6, the voltammetric responses (black dots) were very similar to the measurements obtained with $\mathrm{Cp}$ standard solutions. In fact, the respective slope values of the linear plots were $(-0.30 \pm 0.2)$ and $(-0.30 \pm 0.1) \mu \mathrm{A}$. Therefore, interpolation of the DP voltammetric measurements for the sample into the calibration plot constructed with $\mathrm{Cp}$ standard solutions was employed to quantify Cp. Samples were analyzed by triplicate at five concentration levels (see Table 4) with mean recoveries ranging between 91 and $104 \%$. These results demonstrated the usefulness of the developed magnetoimmunosensor for the analysis of $\mathrm{Cp}$ in serum with just an appropri-
Table 4. Determination of $\mathrm{Cp}$ in spiked human serum with AP$\mathrm{Cp} / \mathrm{Cp}$-anti-Cp-Strept-MBs/SPCE immunosensor.

\begin{tabular}{llc}
\hline $\mathrm{Cp}(\mu \mathrm{g} / \mathrm{mL})$ & $\mathrm{Cp}$ found $(\mu \mathrm{g} / \mathrm{mL})$ & Recovery $(\%)$ \\
\hline 0.05 & $0.050 \pm 0.003$ & $101 \pm 5$ \\
0.10 & $0.094 \pm 0.006$ & $94 \pm 6$ \\
0.25 & $0.23 \pm 0.02$ & $94 \pm 7$ \\
0.50 & $0.45 \pm 0.04$ & $91 \pm 8$ \\
1.00 & $1.04 \pm 0.07$ & $104 \pm 7$ \\
\hline
\end{tabular}

[a] Concentration in the analytical solution.

ate dilution as sample treatment. Moreover, it should be remarked that the high sensitivity of the developed methodology allowed the determination of $\mathrm{Cp}$ in serum at the clinically relevant concentration levels despite the $1: 1000$ dilution factor of the sample.

\section{Conclusions}

Electrochemical immunosensors for the determination of $\mathrm{Cp}$ have been reported for the first time. The development of these immunosensors profited from the advantageous properties of functionalized MBs to carry out the immunoreactions on their surface and not on the electrochemical transducer surface, thus avoiding unspecific bindings on the electrode. Two different configurations involving MBs functionalized with Protein A or streptavidin were developed and analytically compared. The analytical performance of the magnetoimmunosensors can be positively compared in terms of wide linear range, limits of detection, precision and short assay time with that claimed for different immunoassay kits. It is important to remark that the storage stability of the anti-Cp-Biotin- 
Strept-MBs allows the determination to be carried in approximately $35 \mathrm{~min}$, which is a much shorter assay time than that reported for the immunoassays. Therefore, the anti-Cp-Biotin-Strept-MBs immunosensor appears to be highly appropriate for the analysis of $\mathrm{Cp}$ at clinically relevant concentrations in human serum samples. Only an appropriate dilution with buffer was needed as sample treatment to avoid any matrix effect. Although this dilution increases the detection limit attainable in the analysis of serum with respect to that calculated in buffer solutions, the excellent sensitivity of the developed magnetoimmunosensor allows the determination of $\mathrm{Cp}$ to be carried out at the clinically relevant levels in a rapid and simple manner.

\section{Acknowledgements}

Financial support from the Spanish Ministerio de Economía y Competitividad (Project CTQ 2012-35041) and Comunidad de Madrid S2009/PPQ-1642, Programme AVANSENS is gratefully acknowledged.

\section{References}

[1] S. Osaki, D. A. Johnson, E. Frieden, J. Biol. Chem. 1996, 241, 2746.

[2] P. L. Wirth, M. C. Linder, J. Natl. Cancer Inst. 1985, 75, 277.

[3] J. B. Miale, Laboratory Medicine Hematology, 5th ed., The C. V. Mosby Company, London 1977, p. 469.

[4] B. L. Somani, V. Ambade, Clin. Biochem. 2007, 40, 571.

[5] J. D. Korman, I. Volenberg, J. Balko, J. Webster, F. V. Schiodt, R. H. Squires, R. J. Fontana Jr, W. M. Lee, M. L. Schilsky, Hepatology, 2008, 48, 1167.

[6] T. C. Larkin, T. A. Fingleton, M. Mccusker, M. Cassidy, G. Gunter, C. A. Lepp, E. Gamboa, Clin. Lab. 2004, 50, 193.

[7] M. Hosoba, H. Fujita, T. Miura, T. Morii, T. Shimotomai, J. Koshimura, Y. Yamada, S. Ito, T. Narita, Horm. Metab. Res. 2009, 41, 910.
[8] O. Y. Kim, M. J. Shin, J. Moon, J. H. Chung, Clin. Biochem. 2011, $44,351$.

[9] M. Cignarelli, G. DePergola, G. Picca, M. Sciaraffia, N. Pannacciulli, M. Tarallo, E. Laudadio, E. Turrisi, R. Giorgino, Int. J. Obesity 1996, 20, 809.

[10] R. J. Henry, N. Chiamori, S. L. Jacobs, M. Segalove, Proc. Soc. Exp. Bio. Med. 1960, 104, 620.

[11] F. W. Sunderman Jr, S. Nomoto, Clin. Chem. 1970, 16, 903.

[12] K. H. Schosinsky, H. P. Lehmann, M. F. Beeler, Clin. Chem. 1974, 20, 1556.

[13] H. Mukerjee, Clin. Chem. 1990, 36, 391.

[14] J. Winkles, A. F. Jones, P. Winyard, D. R. Blake, J. Lunec, J. Ann. Clin. Biochem. 1988, 25, 250.

[15] O. Erel, Clin. Chem. 1998, 44, 2313.

[16] C. Hammett Stabler, G. Coburn, R. Jordan, W. Winter, Clin. Chem. 1996, 42, 44.

[17] V. López-Avila, O. Sharpe, W. H. Robinson, Anal. Bioanal. Chem. 2006, 386, 180.

[18] E. Pinilla Gil, R. M. Garcia-Moncó Carra, A. Sánchez Misiego, Anal. Chim. Acta 1995, 315, 69.

[19] H. Wang, D. Li, Z. Wu, G. Shen, R. Yu, Talanta 2004, 62, 201.

[20] E. Zacco, J. Adrian, R. Galve, M. P. Marco, S. Alegret, M. I. Pividori, Biosens. Bioelectron. 2007, 22, 2184.

[21] F. Ricci, G. Volpe, L. Micheli, G. Palleschi, Anal. Chim. Acta, 2007, 605, 111.

[22] M. Eguílaz M, Moreno-Guzmán, S. Campuzano, A. González-Cortés, P. Yáñez-Sedeño, J. M. Pingarrón, Biosens. Bioelectron. 2010, 26, 517.

[23] M. Moreno-Guzmán, A. González-Cortés, P. Yáñez-Sedeño, J. M. Pingarrón, Anal. Chim. Acta 2011, 692, 125.

[24] S. Centi, S. Laschi, M. Mascini, Talanta, 2007, 73, 394.

[25] A ntibodies: A Laboratory Manual (Eds: E. Harlow, D. Lane), Cold Spring Harbor, New York 1988.

[26] W. Lee, B. K. Oh, Y. M. Bae, S. H. Paek, W. H. Lee, J. W. Choi, Biosens. Bioelectron. 2003, 19, 185.

[27] F. Darain, S. V. Park, Y. B. Shim, Biosens. Bioelectron. 2003, $18,773$.

[28] M. Díaz-González, D. Hernández-Santos, M. B. GonzálezGarcía, A. Costa-García, Talanta 2005, 65, 565.

[29] I. Ojeda, M. Moreno-Guzmán, A. González-Cortés, P. Yáñez-Sedeño, J. M. Pingarrón, Analyst 2013, 138, 4284.

[30] S. Centi, G. Messina, S. Tombelli, I. Palchetti, M. Mascini, Biosens. Bioelectron. 2008, 23, 1602.
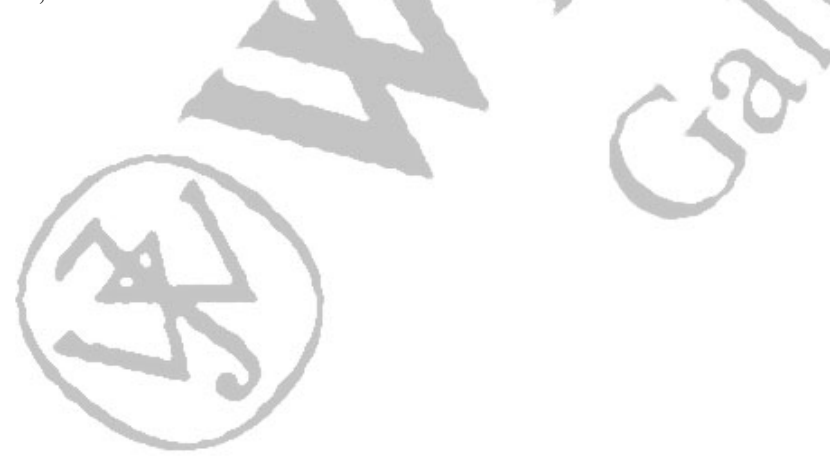